\title{
Developing Students' Reading Comprehension Using STAD Strategy: A Classroom Action Research (CAR) at SMA Negeri 7 Pekanbaru
}

\author{
Asmida Posmauli Marpaung ${ }^{1}$, Indri Yanti ${ }^{2}$, Yuliana Marzuki ${ }^{3}$ \\ ${ }^{1,2}$ SMA Negeri 7 Pekanbaru, Indonesia \\ ${ }^{3}$ Dinas Pendidikan Provinsi Riau, Indonesia \\ mimialmi727@gmail.com
}

\begin{abstract}
ARTICLE HISTORY
Received : 2019-06-09

Revised : 2019-06-11

Accepted : 2019-06-20
\end{abstract}

\section{KEYWORDS}

Reading Comprehension STAD Model

Cooperative type

Classroom Action Research

\begin{abstract}
This study tries to explore the students' improvement on reading comprehension and their results of completeness in learning using STAD type cooperative learning strategy. Using classroom action research (CAR), this study succeeded in finding out that the average score of the class in the first cycle using STAD was found reaching 51.42, while in the second cycle succeed with 74.28. The analysis of this study also reveals the percentage of student learning completeness in the first cycle test reached $21.43 \%$, while the second cycle test managed to increase the score into $85.71 \%$. The percentage of students' understanding in the first cycle showed only $51.42 \%$, while in the second cycle extended into $74.28 \%$. The analysis based on the observation sheet recorded on the first cycle reached $74.30 \%$, while in the second cycle it increased into $91.66 \%$. From The observation sheet for teacher, learning management in the first cycle recorded $84.17 \%$, while in the second cycle it also increased into $90.47 \%$. The data from observation sheet on group discussion in the first cycle managed also recorded $54.76 \%$, while in the second cycle it showed a significant increasing into $90.47 \%$. This study showed that students' reading comprehension has showing a significant increasing using the STAD Cooperative Learning Method in SMAN 7 Pekanbaru.
\end{abstract}

\section{Introduction}

Teaching reading is an integral part of the educational context. This means that teaching reading is positioned as a tool and functional media in educational settings. This line of thinking similar to what Busri, (2002) mentioned in his paper "Teaching reading is an inseparable part of language teaching. In this case teaching reading has a dual position, i.e., as a tool and functional media from language teaching". Therefore in language teaching especially reading there are vary strategies and method to gain the objectives including cooperative learning.

Cooperative learning is developed to achieve at least three learning objectives e.g., academic learning outcomes, acceptance of diversity, and development of social skills. Many scholars argue that this learning is excellent in helping students understand difficult concepts. However, many also researchers have shown that the effectiveness structure model has been able to improve students' assessment of academic learning and norm changes related to learning outcomes. Moreover, the cooperative learning method such as the Student Teams Achievement Division (STAD) is one of the simples' cooperative learning approach. Teachers who use STAD type learning method also refer to student group learning where every week the teacher uses verbal or text presentations. Students in a selected class were divided into groups of 4-5 people, each group must be heterogeneous, consisting of men and women, coming from various ethnic groups, having high, medium and low abilities. Moreover, during this time, unwittingly Indonesian language learning systems in many schools have caused boredom in the learning atmosphere in class. In the sense that the learning environment that should be running conducive turns into a boring, situation, which has implications for the mastery of the material presented both for the teacher or students as well.

Therefore, Indonesian language learning systems in many schools including SMA Negeri 7 in Pekanbaru also get into same situation where the learning of Pelajaran Bahasa Indonesia (henceforth: PBI) seems less satisfied. Based on the learning outcomes of class XI IPS 2 students are seems lower then other classes at the same level. This can be seen from their scoring test. This situation is might caused by the use of learning methods that are used by teachers. The pre research observation found that the method that is often used by teachers is lecturing approach which already considerd old though of school approach. The method seems puts the students into passive condition and the rarity of students asking questions or involving onto interactive situation. Hence, this presents study-assumptions that PBI learnig situation is a boring lesson and always considered easy things that no need to study at all. The 
existence of a series of problems above causes the teaching and learning process activities are not as expected, namely students cannot think creatively and independently.

Today various learning methods appear as choices for teachers in teaching language. Still, the teachers' creativity is compulsory things in applying the chosen learning method including a new method such as cooperative learning method i.e., Student Teams Achievement Divisions (STAD). Therefore, this present study intended to explore and find out whether STAD can raise the students' reading comprehension skills at SMAN 7 Pekanbaru. This present study also intended to find out the result of completeness using STAD cooperative learning method.

In general, this study aims to obtain an objective descriptions of the students' improvement on reading comprehension and their completeness of lesson learned using STAD cooperative learning method. Therefore, this study implemented class action research which is believed can contributed significantly and responsibled to the students improvement on the PBI's output especially in reading comprehension at the class XI IPS 2 of SMA Negeri 7 in Pekanbaru

\section{Reading Comprehension: An Overview}

Many researchrs believed that Reading is an important thing in learning language and at the same time is a complicated one that involves many things aswell, not just reciting writing, but also involves visual activity, thinking, psycholinguistics and metacognitive, Crawley and Mountain, (1995), Rahim, (2008), Wahyuni (2002), Cox (1999), Burns, Roe, da Ross (1996), Mclauhglin \& Allen, (2002), Hubert et al., 1998. Many of the researchers above also mentioned in their studies a similar thought that said as a visual process of reading is the process of translating written symbols (letters) into oral words. As a thought process, reading includes word recognition activities, literal understanding, interpretation, critical reading, and creative understanding. Word recognition can be in the form of reading words using a dictionary (Crawley and Mountain, 1995).

Moreover, three terms are often used to provide the basic components of the reading process, namely recording, decoding, and meaning. Syafi'ie (1999), Rahim, (2008), Wahyuni (2002), Cox (1999), Burns, Roe, da Ross (1996), Mclauhglin \& Allen, (2002) mentioned almost a similar thought that in reading recording refers to words and sentences, then associates them with sounds according to the writing system used, while the decoding process refers to the process of translating graphical sequences into words. The process of recording and decoding usually takes place in the early classes which is known as the beginning reading term. The emphasis on reading at this stage is the perceptual process, which is the introduction of correspondence to the sequence of letters with the sounds of language. Meanwhile the process of understanding meaning is emphasized in the next level. (Syafi'ie, 1999).

While, decoding is the process of interpreting print into speech by promptly matching a letter/ combination of letters (graphemes) to their sounds or phonemes and recognizing the patterns that make syllables as well as words. Nevertheless, in meaning circumstances, let say, there is an area in the brain that deals with language processing and does this process automatically. Decoding skills, readers must also have the skills to understand meaning. Understanding of meaning takes place through various levels, ranging from literal levels of understanding to interpretive, creative and evaluative understanding.

Thus, it can be said that reading is a combination of perceptual and cognitive processes, as stated by Crawley and Mountain (1995). Klein, et al. (1996) suggested that the definition of reading includes (1) reading is a process, (2) reading is strategic, (3) reading is interactive. Reading is a process meant that information from text and knowledge possessed by the reader has a major role in shaping meaning. Reading is also strategic. Effective readers use a variety of reading strategies that are in accordance with the text and context in order to construct meaning when reading. This strategy varies according to the type of text and the purpose of reading. Reading is interactive. The involvement of the reader with the text depends on the context. People who like to read a text that is useful, will meet several goals that they want to achieve, the text that someone reads must be easy to read (readable) so that interactions occur between the reader and the text (Rahim, 2008: 2-3).

People interpret reading in a variety of ways. This is due to the different views of these people on the reading process. Furthermore, Finocchiaro, M., \& Bonomo, M. (1973) defines reading as picking and understanding the meaning or meaning contained in written material. Reading is also interpreted as an ability / skill to see written symbols and change the written symbols through phonics (a method of teaching reading, speech, spelling, based on phonetic interpretation of ordinary spelling) into / towards oral reading (oral reading). Reading is a process of understanding what is implied in the express, seeing the mind in the words contained in written words.

From the definition above this present study emphasized, that reading can be seen as: (1) a process, (2) reading using written media, (3) can be written or read in the heart, and (4) with the main purpose of getting a message/information/meaning written.

Skills or reading comprehension skills emphasized in a number of theories on how to understand reading. In giving the level of reading comprehension, experts vary in terms. According to Dale, E., \& Tyler, R. W. 
(1934), reading comprehension is classified as reading the lines, reading between lines, and reading beyond the linnes. While Oka (1986), classified reading comprehension into explicit reading, implied reading, and highlighted reading. Tarigan classifies reading comprehension into intensive reading and extensive reading. In addition, there are also those that classify reading comprehension into explicit and implicit reading.

Whatever their classification of reading comprehension, in principle they distinguish between reading the visible comprehension of the text, and reading comprehension behind the text. The following is a classification of the level of reading comprehension using the term Russell, Mrtha L King, E.Echorch, in Wahyuni (2002) namely literal reading ability, critical reading skills, and creative reading skills.

Nevertheless, some studies also showed that many factors influence the success of reading in language classroom in many institutions. McLaughlin \& Allen (2002), elaborate and discuss most influence factors including the principles of reading based on their research on reading comprehension are as stated below:

a) Understanding is a social constructivist process, constructivist theory views understanding and structuring language as a building process. This is inline to what Cox (1999) argues that children constantly build new meanings on the basis of their prior knowledge for the communication process.

b) Equity Balance is a curriculum framework that helps development of understanding and a curriculum that gives the same position between reading and writing and recognizing the importance of the cognitive and effective dimensions of justice. Literacy of meaning makes it involved in the process of reading and writing fully, even though it recognizes the importance of the strategies and skills used by expert readers and writers.

c) Professional (superior) reading teachers affect student learning. A superior teacher is aware of what is done well and what students need to succeed. Superior teachers know the importance of each student having a literacy experience. Expert teachers are teachers who make a difference in student success.

d) The role of the teacher in the reading process, among others, creates experiences that introduce, maintain or expand students' abilities to understand the text. This requires the teacher to carry out learning directly, modeling, and helping to improve, facilitate, and participate in learning.

e) A good reader holds a strategic role and plays an active role in the reading process. In the new paradigm, the curriculum emphasizes the strong relationship between justice and content. Students learn the importance of reading, writing, and thinking critically for the effectiveness of independent learning. They learned how to use literacy as a tool to find and master the contents of the reading. Legal-based strategies support the new curriculum by emphasizing the process of learning, critical thinking, and monitoring oneself.

f) Reading should occur in meaningful contexts. Students need to familiarize themselves with the text every day in various levels of difficulty. When the level of text that is being used the teacher helps, students improve their learning experience and students receive various levels of support, depending on the goals and teaching settings. For example, if the text is a challenge, the teacher can use loud reading to provide full support to students. If the text is right for learning, students have support as needed, with teacher encouragement or responses if required. Moreover, students discover the benefits of reading originating in various texts at different levels of class. Students need to read daily texts from different levels. If the text level is to be used, the teacher should provide assistance to improve and broaden the student's learning experience, so students receive various levels of support depending on the goals and teaching settings. Interlinking with various types of reading material will surely enhance students' understanding (Hamuddin, 2016).

g) Development of vocabulary and learning affects reading comprehension. Social constructivist theory plays an important role in the development of vocabulary. According to Burns, Roe, da Ross (1996) it is difficult to determine the right age to learn the exact meaning of words. Beginning in the process of language development, they learn to distinguish antonyms, synonyms, meanings of multiple meanings, abstract definitions, and so on. In addition, Snow, Griffin \& Burns (2007), Mclauhglin \& Allen, (2002) has similar thought that "learning new concepts and words that encode them is an important development of understanding".

h) Participation is a key factor in the understanding process. The involvement of readers transact with prints builds an understanding based on the relationship between prior knowledge and new information. Mclauhglin \& Allen, (2002) describes the process of thinking and suggesting being part of the story in their minds. Teachers can maintain and develop it by encouraging students to read for clear and tangible goals and respond in ways that are meaningful, as well as always focusing on understanding, personal relationships and readers' responses. 
i) Reading strategies and skills can be taught. In many recet studies also demonstrated that when students experience a direct understanding strategy, the strategy increases the understanding of the text about new topics. Understanding questions often arise at the level of literal understanding, assigned and then corrected, understanding is assessed but not taught (Hubert et al., 1998). Linking skills and strategies can make it easier for students to understand comprehension strategies that are generally more complex than comprehension skills.

j) Dynamic assessment informs reading reading comprehension. Assessment is a collection of data, such as test scores and informal records to measure student learning outcomes, while evaluation is the interpretation and analysis of data.

k) Assessing student progress is important because it allows the teacher to find strengths and weaknesses, plan teaching appropriately, communicate student progress to parents, and to evaluate the effectiveness of teaching strategies.

The factors and some principles above being the line of thinking of this present study which opening an assumptions that in developing studnets reading comprehensions it needs whatt might it called as an appropriate and effectif teaching strategy that covert all its necessary things of it. Therefore this study believed that cooperative learning i.e. Student Team Achievement Division (STAD) will be so much needed due to the uniqueness of this strategy.

\section{STAD Cooperative Learning}

The Student Team Achievement Division (STAD) Cooperative Learning Type developed by Robert Slavin and his friends at John Hopkin University (in Slavin, 1995) is the simplest cooperative learning, and is cooperative learning suitable for use by teachers who are just starting to use learning cooperative. STAD is one of the simplest types of cooperative learning. Where in this study, students placed in a learning team consisting of four people, which was a mixture according to their performance level, gender and ethnicity. The teacher presents lessons then students work in teams to ensure that all team members have mastered the lesson.

Finally, all students were given a quiz about the material with notes, when they quiz they should not help each other. The STAD is an approach uses cooperative learning model that emphasizes activities and interactions between students to motivate each other and help each other in mastering subject matter in order to achieve maximum achievement.

Moreover, teachers who use STAD submit new academic information to students every week using Verbal or text presentations. The procedure of the study begins with a pre-action which is to identify the STAD Cooperative Learning method and Reading
Comprehension and then take an action consisting of 3 cycles. Each cycle of action has four stages, namely:

a) Preparation of actions,

b) Implementation of actions,

c) Observation and evaluation,

d) Analysis and reflection.

These four stages will be elaborate in detail as follows:

\subsection{Preparation of Action}

a) Prepare a learning implementation plan that refers to the syllabus of the discussion that has been made by the teacher.

b) Prepare teaching materials.

c) Preparation of instruments as observation tools.

(1) A sheet of students' ability to read and understand.

(2) Observation sheet of problems encountered to improve reading comprehension of students.

d) Determination of schedule of class actions.

\subsection{Implementation of Action}

The actions of each class in general are as follows:

a) The teacher conveys all the objectives of the lesson to be achieved in the lesson and motivates students to learn.

b) The teacher presents information to students by way of demonstrations or through reading material.

c) The teacher explains to students how to form study groups and help each group to make the transition.

d) The teacher guides the study groups when they do their assignments.

e) The teacher evaluates the results of learning about the material that has been studied or each group.

f) The teacher rewards both efforts and individual or group learning outcomes.

\subsection{Observation and Evaluation}

In the implementation of the action in the first cycle, the teacher provides learning material reading comprehension by the cooperative method type STAD. From the results of observations and reflections on cycle I, information was obtained that if student activities are still not optimal or they are still having difficulty adapting to group members to solve problems and are still dependent on the teacher. In other words, the cooperative implementation of the STAD type still not maximal and there are many shortcomings, the teacher will fix it at the stage of implementation of action II. 


\subsection{Reflection and Analysis}

Reflection is carried out to analyze the results of the action as an improvement material for the next action.

\section{Methodology}

The type of research used is action research, namely researchers trying to implement an action as an improvement effort to overcome the problems found. Classroom action research, using a model designed by Kemmis and Mc Taggart (in Suranto, 200: 49), this model uses a self-reflection spiral system that starts from the plan, action, observation, reflection, and replanning which is the basis for a design solution to problem.

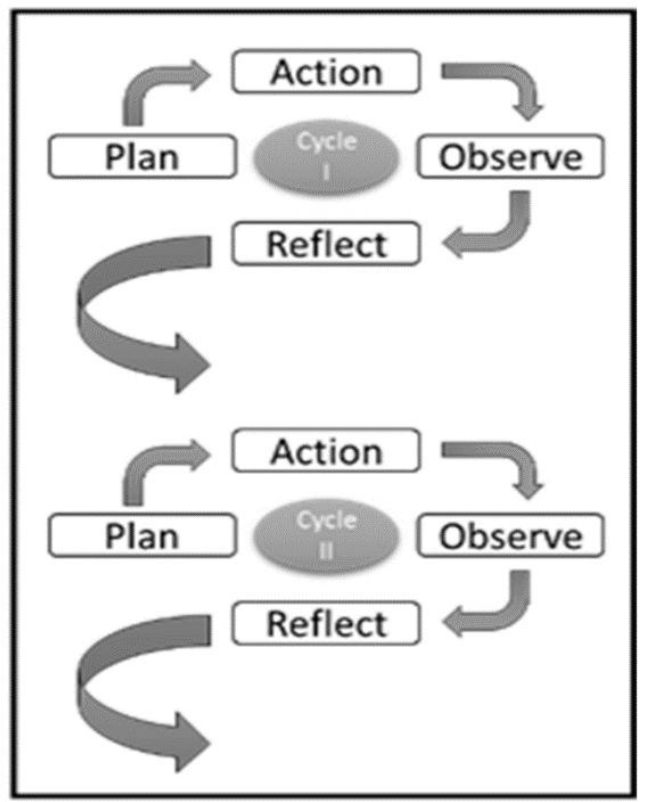

Figure 4.1 Classroom Action Research Cycle

\section{Findings}

\subsection{Increased Understanding}

Based on the results of data analysis, information was obtained that students' understanding of material indicators of understanding sentences and understanding paragraphs had increased. The increase in discourse understanding in the first cycle was $53.37 \%$ and then increased in the second cycle to 80 , $71 \% 27.14 \%$.

This shows that students' understanding has increased from cycle I to cycle II. Students' understanding of this indicator is obtained from the answers to the final test cycle questions. Through this answer it can also be known how students can understand the intent of the problem, write down what is known and what is asked. This shows that the increase in students' understanding of learning is due to the application of the STAD type cooperative method.

\subsection{Learning Completeness}

From the results of data analysis, the percentage of students 'mastery learning in the first cycle was $21.43 \%$ and in the second cycle was $85.71 \%$, meaning that the percentage of students' mastery learning had increased. In the second cycle, the percentage of students' mastery learning has reached the KKM used by BI teachers at SMA 7 Pekanbaru, ie $80 \%$ of students achieve a test score of 80 (scale 1-100) and the class average reaches a score of 80 (scale 1-100).

Student learning completeness is due, the application of the STAD type cooperative method is a learning method designed in the form of group learning. By learning groups of students are expected to be more active and can work together in solving problems they face. In accordance with the opinion of Nurhadi et al (2004: 47), in general the results of group work are better than active individual work, not passive individuals

\section{Discussion and Suggestion}

Based on the results of data analysis and discussion in this study, it was found that the application of the STAD type cooperative learning method to improve understanding of sentences and understanding paragraphs had been carried out in four stages, namely: class presentations, group work, tests (quizzes) and team recognition.

At the presentation stage the teacher explains the reading comprehension material by emphasizing on the STAD unit. With this emphasis, students will really pay full attention during class presentations. Next, at the stage of group work, before this stage is carried out, the teacher first divides students into several groups consisting of four or five students heterogeneously.

Moreover, at this stage students work and discuss to discuss and complete the assignments given by the teacher. In group work students have a responsibility to ensure that teammates have studied and understood the material. Then, the test or quiz takes place around one or two periods after class presentations and group work. Tests are used to determine student mastery individually of the material that has been studied. The test results will be an individual improvement point which is then given as a determinant of the group's predicate. Furthermore, group recognition is an appreciation for group success. Awards were given after each group received the title of the group according to the criteria in STAD, namely the group was quite good, good, very good, and super group.

Therefore, this study somehow can shows that STAD cooperative learning is worthed enough to try. It seems through $\mathrm{SAD}$ students has a significant improvement score every cycle, and showing significant different comparing with their result previously when they learning PBI with the classical 
teaching method. It seems the students feel interested to learn than before when they were taught by conventional method that make they sometimes feel bored in the classroom and lack of interest to attendances in teaching and learning process. STAD cooperative learning seems succeed based on the quantitative scoring and contributes as the students' reinforcement in learning Reading comprehension in PBI classroom. However during this research conducted there are so many notes been recorded to improve learning environment especiall in PBI class that somehow this study need to share as a suggestion.

Using STAD cooperative learning in teaching Reading comprehension is just an example of how the cooperative learning environemnt can help the students and teacher in teaching and learning PBI. From this study point of view it would like to point some extra words as follows:

a) It is better for the Teacher and the students' to use STAD cooperative learning in teaching and learning activities to improve their reading comprehension.

b) The teachers should be more ready and literate to know and to try the positive benefits of using cooperative learning or media in class and knowing its effects on the students.

c) The researcher recommend the lecturer to use STAD or other cooperative learning method as and approach or strategy as well as media support in students' learning activity.

\section{Conclusion}

The results of data analysis in this study found that the average value of the class in the first cycle test reached 51.42, while in the second cycle reached 74.28. The percentage of student learning completeness in the first cycle test reached $21.43 \%$, while the second cycle test reached $85.71 \%$. The percentage of students' understanding in the first cycle reached $51.42 \%$, while in the second cycle it reached $74.28 \%$. For the observation sheet the activity of students in the first cycle reached $74.30 \%$, while in the second cycle it reached $91.66 \%$. The observation sheet for managing teacher learning in the first cycle reached $84.17 \%$, while in the second cycle it reached $90.47 \%$. The group discussion observation sheet in the first cycle reached $54.76 \%$, while in the second cycle it reached $90.47 \%$.

From the observations, it shows that $75 \%$ of the success criteria. The result above shows that students' understanding of reading comprehension material has increased. From the description above, it can be concluded that the application of the STAD type cooperative method can improve reading comprehension of XI IPS 2 students in Pekanbaru 7 High School.

\section{Acknowledgement}

This research was supported by SMA Negeri 7 Pekanbaru. Therefore, we thank our colleagues as well who provided insight and expertise that greatly assisted the research, although they may not agree with all of the conclusions of this paper.

\section{References}

Arikunto, S. (2002). Prosedur Penelitian. Jakarta: Rineka Cipta.

Arikunto, S. (2008). Penelitian Tindakan Kelas. Jakarta: Bumi Aksara

Dale, E., \& Tyler, R. W. (1934). A study of the factors influencing the difficulty of reading materials for adults of limited reading ability. The Library Quarterly, 4(3), 384-412.

Finocchiaro, M., \& Bonomo, M. (1973). The foreign language learner: A guide for teachers. New York: Regents.

Hamuddin, B. (2016). Using blog to Promote English Skills for EFL Students: The Students' Perception. ELT-Lectura, 3(2).

Herlinawati, H., \& Abbas, M. F. F. (2017). Who Gains the Benefits of On-Task Versus Off-Task SelfAssessment? Higher or Lower Proficiency?. Lectura : Jurnal Pendidikan, 8(2). https://doi.org/10.31849/lectura.v8i2.343

Keraf, G. (1984). Komposisi Sebuah Pengantar Kemahiran Bahasa. Jakarta : Nusa Indah.

Lestari, S., \& Syaifullah, S. (2017). A Narrative Research: a Student's Strategies in Reading Comprehension on TOEFL at the Eighth Semester of English Education Department of Lancang Kuning. ELT-Lectura, 4(2).

Marwa, M. (2014). Reasons for Students' CodeSwitching Between Informal Indonesian and English in ELT Contexts. ELT-Lectura, 1(1). https://doi.org/10.31849/elt-lectura.v1i1.446

Moleong, L. J. (2006). Metodologi Penelitian Kualitatif Edisi Revisi, Cetakan keduapuluh dua, Bandung: PT. Remaja Rosdakarya Offset.

Nurhadi and Senduk. (2005). Pembelajaran Kontekstual (Contextual Teaching and Learning/CTL) dan Penerapannya Dalam KBK. Malang: UM.

Oka, E. R. (1986). Reading Skills in Underachieving Children. Handbook of cognitive, social, and neuropsychological aspects of learning disabilities, 2, 115.

Rahim, F. 2008. Pengajaran Membaca di Sekolah Dasar. Jakarta: PT Bumi Aksara. 
Ramlan, M. (1986). Sintaksis. Yogyakarta : CV. Karyono

Sanjaya, W. (2008). Strategi Pembelajaran Berorientasi Standar Proses Pendidikan. Jakarta: Kencana.

Setyosari, P. (2001). Rancangan Pembelajaran Teori dan Praktek. Malang: Elang Mas

Silaban, A. L., \& Andriani, R. (2017). Using Flyswatter Game To Improve Students' Vocabulary Mastery At Grade Eigth SMP Dwi Sejahtera Pekanbaru. ELT-Lectura, 4(2).

Snow, C., Griffin, P., \& Burns, M. S. (Eds.). (2007). Knowledge to support the teaching of reading: Preparing teachers for a changing world. John Wiley \& Sons.

Sukardi. (2003). Metodologi Penelitian Pendidikan Kompetensi dan Praktiknya. Jakarta: Bumi Aksara.

Surianta, M. (2008). Penerapan Model Pemebelajaran Kooperatif Type STAD Deangan Media VCD, (Online), (http:/journal. Diakses 23 Mei 2013).

Syaifullah, S. (2019). The Analysis of Students'ability on Listening Comprehension of Toefl Testat Sixth Semester Students of English Education Department Lancang Kuning University Pekanbaru. PROCEEDING IAIN Batusangkar, 3(1), 313-322.

Wahyuni, S. (2010). Evaluasi Pembelajaran Bahasa dan Sastra Indonesia. Malang Unisma. 